International Review of Social History 44 (1999), pp. 197-215

(C) 1999 Internationaal Instituut voor Sociale Geschiedenis

\title{
Work and Workloads During Industrialization: The Experience of Forgemen in the British Iron Industry I750-1850
}

\author{
CHRIS Evans
}

Summary: This article examines the ways in which working practices and workloads changed in the course of British industrialization by tracing the experience of one group of skilled workers: iron forgemen. A well-established historiographical tradition assumes that workers were subjected to a more burdensome discipline during the Industrial Revolution. However, empirical studies of workplace practice in early industrial Britain are scarce, and those few studies that have been attempted stress the continuity of workers' experience. But this study argues for discontinuity, exploiting a range of data on the output levels achieved by individual forge crews c. I750-C. I850 to identify substantial increases in the burdens imposed upon forgemen.

\section{INTRODUCTION}

In what ways did the nature of work change during British industrialization? Was work becoming harsher? More intensive and unremitting? The emergence of the factory as a carceral, mechanized working environment would seem to suggest that this was so. Those who pioneered the study of the Industrial Revolution on a professional basis in the late nineteenth century certainly believed that something fundamental had altered in the human experience of labour. Drawing upon a popular identification of the factory with "slavery" that was present almost from the inception of a factory system in Britain, and upon an aesthetic rejection of industrialism that was common to many among the Victorian intelligentsia, progressive intellectuals took it as axiomatic that work had become more intense during the Industrial Revolution. ${ }^{2}$ Historians such as John and Barbara Hammond

I. This paper is based upon research supported by the Regional Research Programme of the University of Glamorgan. The argument owes much to Göran Rydén of the Department of Economic History, University of Uppsala, whose own work in this area has been a great stimulus. I am grateful to Penelope J. Corfield, Andy Croll and Neil A. Wynn for their comments on earlier versions of this paper.

2. M. Berg, The Machinery Question and the Making of Political Economy I8I5-I848 (Cambridge, 1980); R. Gray, The Factory Question and Industrial England, I830-I860 (Cambridge, I996); M. J. Wiener, English Culture and the Decline of the Industrial Spirit, I850-1980 (Cambridge, 1981). 
championed this view in their pathbreaking study The Town Labourer (I917), making the imposition of a more punitive regime within the workplace part of a broader narrative of deprivation and political exclusion. Early industrial society in Britain was a "Bleak Age" in which the common people suffered not just a deterioration in living standards and a denial of political rights, but a more punishing and regimented working life as well. ${ }^{3}$

The picture drawn by the Hammonds was to be highly influential. E. P. Thompson, the most distinguished modern representative of the Hammond school, made a forcible restatement of the association between capitalist industrialization and the disempowerment of workers in his 1967 essay "Time, Work-Discipline and Industrial Capitalism". ${ }^{4}$ In this, he attended to long-term cultural shifts surrounding the understanding of time and its management in early capitalist society. Yet Thompson did not analyse actual workplace practice in any sustained or systematic fashion. His purpose was to illuminate the intellectual and cultural foundations of a more intensive discipline in early industrial society, not to investigate the ways in which that discipline assumed concrete form within the workplace. The critical response to Thompson - which has been considerable - has followed suit. Relatively little attention has been given to the question of what workers actually did at work. Instead, commentators have tended to focus upon the conceptualization of time in different historical contexts. Thompson's account of the key transition from task-based time to clock-based time has been criticized for being overly linear, for failing to take full cognizance of the multiple ways in which time was construed and organized by working people, defying or modifying the triumph of clock-measured time. ${ }^{5}$

3. J. L. Hammond and B. Hammond, The Town Labourer (I917: London, 1978), pp. I2-I5. See also D. Cannadine, "The Present and the Past in the English Industrial Revolution", Past and Present, I03 (1984), pp. 133-139, and D. Sutton, "Radical Liberalism, Fabianism and Social History", in R. Johnson, G. McLennan, B. Schwarz and D. Sutton (eds), Making Histories: Studies in History Writing and Politics (London, 1982), pp. 15-43.

4. E.P. Thompson, "Time, Work-Discipline and Industrial Capitalism", Past and Present, 38 (1967), pp. 56-97. See also S. Pollard, The Genesis of Modern Management: A Study of the Industrial Revolution in Great Britain (Harmondsworth, 1968), pp. 213-23I; D. A. Reid, "The Decline of St Monday, I766-I876", Past and Present, 7I (1976), pp. 76-IoI; D. A. Reid, "Weddings, Weekdays, Work and Leisure in Urban England, I79I-I9II: The Decline of Saint Monday Revisited”, Past and Present, I53 (1996), pp. I35-I53.

5. S. L. Kaplan and C. J. Koepp (eds), Work in France: Representations, Meaning, Organization and Practice (Ithaca, NY, 1986); P. Joyce, Visions of the People: Industrial England and the Question of Class, 1848-I9I4 (Cambridge, I99I); M. Roberts, "The Empty Ladder: Work and its Meanings in Early Modern Cardiganshire", Llafur, 4 (1995), pp. 9-29; M. Sonenscher, "Work and Wages in Paris in the Eighteenth Century", in M. Berg, P. Hudson and M. Sonenscher (eds), Manufacture in Town and Country before the Factory (Cambridge, 1983), pp. 147-172; W. M. Reddy, Money and Liberty in Modern Europe: A Critique of Historical Understanding (Cambridge, 1987); R. Whipp, "A 'Time to Every Purpose': An Essay on Time and Work", in P. Joyce (ed.), The Historical Meanings of Work (Cambridge, 1987), pp. 210-236. See also M. Harrison, "The Ordering of the Urban Environment: Time, Work and the Occurrence of Crowds, 1790-1835", Past and Present, IIo 
So can anything be said about what workers did during the time they were "at work"? In particular, what targets were set for them, and to what extent did they change over time? Such questions are famously difficult to answer. To outside observers the early industrial workplace in Britain was a shadowy environment whose inhabitants did not always welcome scrutiny by strangers. Even employers, whose instructions were frequently put into effect by subcontractors, might have only a partial knowledge of daily activity in their workshops. Historians, in their turn, have also found the workplace to be an impenetrable place. Not only do they have to disinter a complex of now-lost labour processes and practices, but the detailed production records which might be of assistance to them have been almost entirely lost. It is not surprising that empirical studies of working hours and conditions of work in early industrial Britain remain rare. ${ }^{6}$ But interestingly, one of the few that has been attempted closes with a flat denial that the nature of work was transformed in the course of industrialization. Eric Hopkins concluded a survey of industrial development in the West Midlands with this rebuke to Thompson:

[...] to suggest that during the classic years of the Industrial Revolution the majority of workers in this region (and perhaps elsewhere) were forced to assume new work habits and become the slaves of a new time discipline is really a very doubtful proposition, and its unthinking repetition can only serve to perpetuate a historical myth. $^{7}$

Workers were not subjected to a worsening in their conditions of labour. In Hopkins's view, only mechanization could effectively deprive workers of the ability to regulate their own working routines, and in the West Midlands - as in British industry as a whole - the mechanization of production proceeded very slowly.

Can this conclusion be accepted? There are some immediate problems. The assumption that mechanization ("machinofacture") was an essential preliminary to a tightening of workplace discipline is belied by the careers of some notorious industrial martinets, such as Josiah Wedgwood and Sir Ambrose Crowley, who operated in sectors in which mechanization featured only very partially. ${ }^{8}$ More importantly, while chastising Thompson for his

(1986), pp. I34-168, for an argument that associates the evolution of a standardized working day with urbanization rather than industrial capitalism.

6. See the survey in N. L Tranter, "The Labour Supply, I780-I860", in R. Floud and D. McCloskey (eds), The Economic History of Britain since I700, vol. I, I700-I860 (Cambridge, I98I), pp. 2I8$22 \mathrm{I}$.

7. E. Hopkins, "Working Hours and Conditions during the Industrial Revolution: A Reappraisal”, Economic History Review, 2nd series, 35 (I982), p. 66. See also M. A. Bienefeld, Working Hours in British Industry: An Economic History (London, 1972), pp. 8-4I.

8. M. W. Flinn (ed.), The Law Book of the Crowley Ironworks (Publications of the Surtees Society, I67, 1957); M. W. Flinn, Men of Iron: The Crowleys in the Early Iron Industry (Edinburgh, 1962), pp. I84-25I; N. McKendrick, "Josiah Wedgwood and Factory Discipline”, Historical Journal, 4 (196I), pp. 30-55. See the useful surveys in K. Bruland, "The Transformation of Work in European 
reliance on prescriptive or homiletic literature as evidence, Hopkins's own argument does not rest upon concrete study of the early industrial workplace as such; it rests upon testimony contained in government reports of the mid- or late nineteenth century, a far from unproblematic source for industrial change in the late eighteenth and early nineteenth century. Such testimony is used to suggest that working hours were stable over the long run. It is not used (or cannot be used?) to address the more pertinent question: what was expected of workers whilst they were within the workplace? Was work becoming more burdensome?

It is here that the experience of forgemen in the British iron industry can be of use. Enough is known of the forge trade to offer the possibility of penetrating the sphere of production and reconstructing the burdens of work, and of doing so over a reasonably lengthy period of time. Importantly, direct comparisons can be made between the work expected of forgemen in the mid-I70os and their successors one hundred years later, despite the revolutionary changes which transformed the iron industry in the intervening decades as charcoal was superseded by mineral fuel. Although the iron puddler of the mid-nineteenth century worked in a plant that was very much larger than the charcoal forge of old, next to rolling mills that exploited steam power to the full, the tasks he had to perform would have been quite recognizable to a charcoal forgeman of the previous era. In both cases forge workers were expected to load pig iron into a hearth, to manipulate molten or viscous metal with nothing more than hand tools, and then to drag bodily a radiant mass of refined iron from the hearth. This was done without mechanical aid of any sort. A direct comparison can therefore be made between the burdens imposed on forgemen in what - on the face of things - might appear to have been very different technological environments. ${ }^{9}$ The data at our disposal do not form a continuous series, but there is sufficient to allow some firm conclusions to be drawn about the experience of individual work crews. The evidence presented below is consistent in showing a dramatic increase in the workloads imposed upon forgemen between the mid-eighteenth and the mid-nineteenth centuries.

This paper will chart forgemen's changing experience of work. It will do so firstly by outlining the technology and patterns of labour organization which prevailed in the charcoal forge trade in the middle of the eighteenth century. Then, an examination will be made of the new, heightened workloads which were a feature of the early nineteenth century following the triumph of iron puddling. Finally, some brief remarks will be made about

Industrialization", in P. Mathias and J. A. Davis (eds), The First Industrial Revolutions (Oxford, 1989), pp. 154-169, and G. N. von Tunzelmann, "Technological and Organizational Change in Industry during the Early Industrial Revolution”, in P. O'Brien and R. Quinault (eds), The Industrial Revolution and British Society (Cambridge, 1993), pp. 254-282.

9. The comparison is close but not completely exact. See note 29 below. 


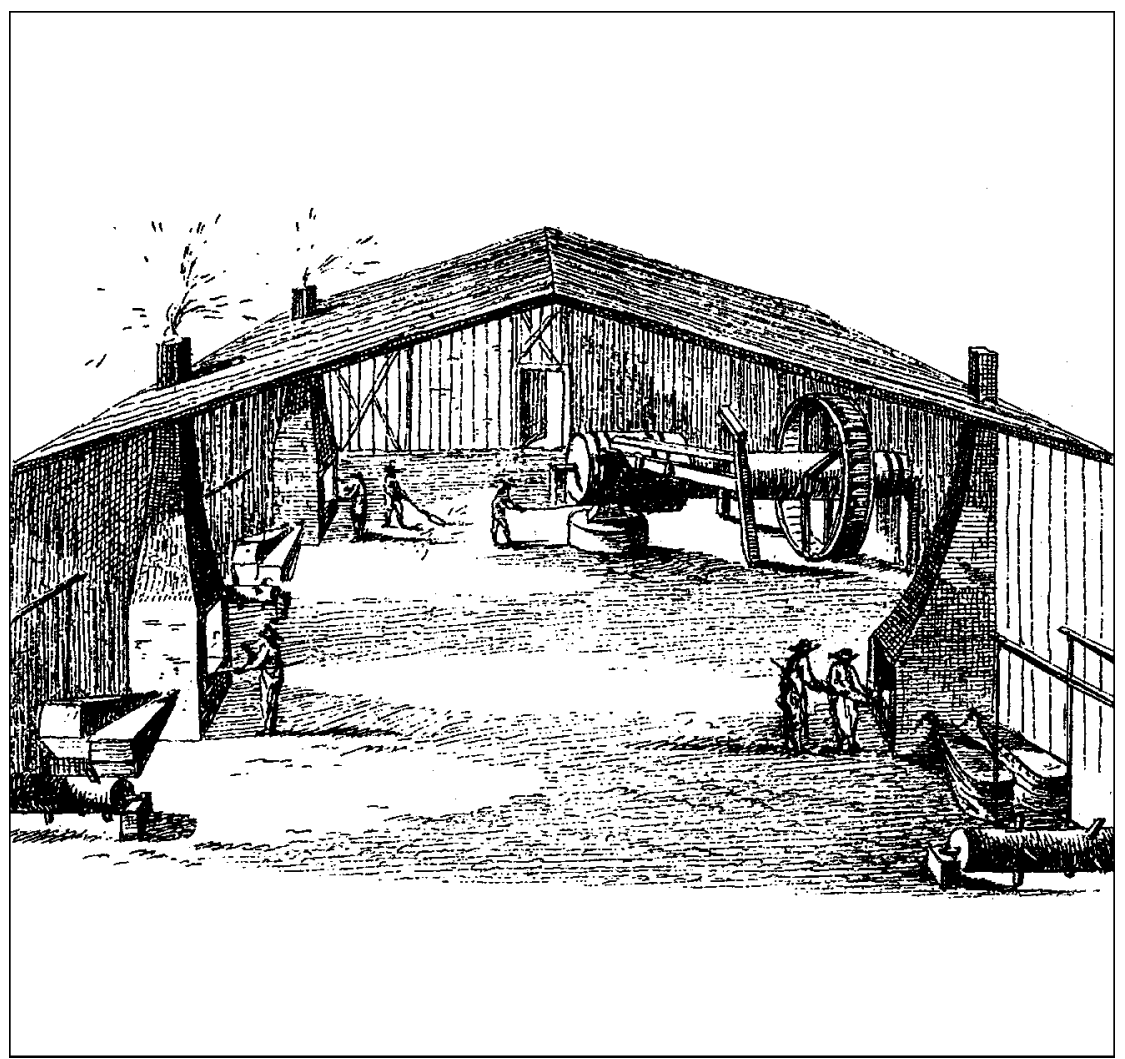

Figure I. Sketch of an English forge by the Swedish traveller Angerstein in the early I750s. Jernkontoret Library, Stockholm

the significance of these findings for the historiography of the British Industrial Revolution.

I

The introduction of the blast furnace to the British Isles in the early modern period had allowed a major increase in iron output, far outstripping the small, batch production achieved by medieval smelters. But the pig iron produced at blast furnaces was heavy with carbon and therefore brittle. It had to be refined at a forge and converted into a malleable iron that could be reheated and reshaped repeatedly under the smith's hammer. The process of conversion was performed by forgemen. Or more accurately, the labour of two distinct grades of forgemen was required. The first of these, the finers, worked at a charcoal-fired hearth (the finery) in which pigs of iron were melted. A pig was pushed into the hottest part of the hearth where 
water-powered bellows intensified the combustion of the charcoal. Here, the end of the pig began to liquefy. Most of the carbon impurities in the iron were oxidized in the air blast, and droplets of decarburized metal fell to the bottom of the hearth, coagulating into a mass of white-hot iron and slag debris (a "loop"). Once a sufficient volume of iron had amassed, the finers dragged the loop from the hearth and subjected it to a heavy waterdriven hammer which pounded out the slag and consolidated the iron into a squared-off lump known as a "bloom". The chemical transformation being complete, the bloom was passed to the other grade of forgeman, the hammermen. The hammermen reheated the bloom at their own hearth (the chafery) and used the forge hammer to flatten and elongate the bloom into a thin bar some two metres or so in length, the form which malleable iron took as a international commodity. ${ }^{\text {IO }}$

Under this system, known as Walloon forging, finers normally worked in teams of three. The finery hearth would be watched over by a master finer who was assisted by a "bloom maker" and (usually) an apprentice. The chafery was worked by a forge crew comprising the master hammerman, the "hammerman's man" and (usually) an apprentice. Because the hammer crew was able to process blooms faster than the finers could produce them, it became conventional for two finery hearths to be coupled with a single chafery, meaning that the typical Walloon forge in Britain employed nine forgemen. ${ }^{\text {II }}$

Success in the making of bar iron depended upon the discretion and knowledge of the skilled forgeman, someone who had been schooled in the management of that most unmanageable of elements, fire. The possession of this knowledge was enough to make the forgeman a specialized and much sought-after industrial worker. And the specialized status of the forgeman was enhanced by the dynastic character of labour organization. Walloon forging had first been introduced to the British Isles by migrant workers from Normandy in the late fifteenth century and the descendants of these pioneers remained prominent within the trade for many decades afterwards. ${ }^{\mathrm{I}}$ Indeed, even in the late eighteenth century, forgemen bearing ang-

IO. H. R. Schubert, History of the British Iron and Steel Industry, from c.45o B.C. to A.D. I775 (London, 1957), pp. 27I-29I, describes workplace practice, drawing upon late seventeenth and early eighteenth-century sources. A. C. Jones and C. J. Harrison, "The Cannock Chase Ironworks, 1590", English Historical Review, 93 (1978), pp. 795-810, describes slightly different procedures a century earlier.

II. The forgemen were usually supported by a smith and a forge carpenter who maintained the plant. There was also, of course, a very much larger indirect labour force of colliers and hauliers who produced and delivered charcoal. This analysis of the workforce is based on G. Rydén, Production and Work in the British Iron Trade in the Eighteenth Century: A Swedish Perspective (Uppsala Papers in Economic History, Research Report no. 45, 1998).

I2. B. G. Awty, "The Continental Origins of Wealden Ironworkers, I45I-I544”, Economic History Review, 2nd series, 34 (198I), pp. 524-539; J.-F. Belhoste, Y. Lecherbonnier, M. Arnoux, D. Arribet, B. G. Awty and M. Rioult, La Métallurgie Normande XIIe-XVIIe Siècles. La Révolution du Haut Fourneau (Paris, 199I), pp. 297-299. 
licized French names were still ubiquitous in the industry. These family groups showed an extraordinary endurance, monopolizing technical knowledge across the generations and forming a network which facilitated the movement of labour from district to district, thereby underpinning a labour market that was genuinely national in extent. ${ }^{13}$ The continuing eminence of these old forge dynasties was possible because the direct labour force in the British forge trade was never large. The finite quantity of charcoal available to the industry ensured that that was the case. Inventories taken in the mid-1730s and in 1749, on the eve of the transition to mineral fuel, suggest that bar iron was made at between $\mathrm{I} 2 \mathrm{O}$ and $\mathrm{I} 3 \mathrm{O}$ sites in England and Wales. ${ }^{\mathrm{I}}$ These figures imply that the charcoal forge trade, even at its greatest extent in the mid-eighteenth century, never needed much more than a thousand forgemen.

The compact nature of the industry perpetuated the hold of oldestablished forge dynasties over the conduct of work. The recruitment of apprentices was a matter for the master forgeman, not the ironmaster. Ironmasters might wish "to Encourage the Head Workmen to take apprentices", but they appreciated that they could not compel their master hammermen or finers to do so. ${ }^{\text {Is }}$ The composition of forge crews was left very largely as a matter for the forgemen themselves. Control over the pace of work also eluded the ironmasters. Because forgemen alone were masters of the labour process, the influence of employers over the conduct of work came at one remove, through a strict audit of the materials that were issued to forgemen. Work was monitored by a stocktaker whose accounts tracked the movement of materials through the forge. Forgemen had to meet production norms based upon an assumed wastage of material during production. ${ }^{16}$ In effect, pigs of iron or blooms were "put out" to forge crews. The thoroughness with which they worked up these materials was measured, not the speed

13. C. Evans and G. Rydén, "Kinship and the Transmission of Skill: Bar Iron Making in Britain and Sweden, I500-I800”, in M. Berg and K. Bruland (eds), Technological Revolutions in Europe, I700-I860 (Cheltenham, I998), pp. I88-206; C. Evans, "A Skilled Workforce during the Transition to Industrial Society: Forgemen in the British Iron Trade, I500-1850", Labour History Review, 63 (1998), pp. I43-I59; C. Evans, "Die Sozialen Grundlagen der Eisenverhüttung in England und Wales (1500 bis I80o)", in D. Ebeling and W. Mager (eds), Protoindustrie in der Region. Europäische Gewerbelandschaften vom I6. bis I9. Jahrhundert (Bielefeld, I997), pp. 359-380.

I4. E. W. Hulme, "Statistical History of the Iron Trade of England and Wales, 1717-1750", Transactions of the Newcomen Society, 9 (1928/29), pp. 25, 27. This conclusion is confirmed by later surveys in 1788 and 1794: Science Museum Library, MS 371/I, fo. 86; Birmingham City Library, Archives Division, Boulton \& Watt MSS, MII/5/Io.

15. Carmarthenshire Record Office (hereafter CRO), Trostre 22, Reynolds Getley \& Co. to Joseph Vaughan, I8 February I775.

I6. At Melingriffith forge finers were allowed a wastage of twenty-five per cent by weight in melting down ("sinking") pig iron into blooms. For hammermen the margin was narrower; they were after all merely reshaping the blooms, not effecting a major chemical change. Blooms were delivered to a hammer crew in "longweight tons" of 2400 pounds. For every ton so received, they had to return a "shortweight ton" of 2240 pounds. 
with which they did so. As a result, the intensity of production could vary at the forge crew's discretion. This might seem paradoxical, since forgemen worked a regular six-day week, beginning with the firing of the hearths in the early hours of Monday morning and continuing to the end of the working week on Saturday evening. ${ }^{17}$ The distribution of effort across those six days, however, was by no means fixed. A distinction was drawn between working "single-hand" and - what appears to have been more common working "double-hand". Double-hand working involved round-the-clock production by the full three-man forge crew. A rota of overlapping shifts ensured that at any one time two of the three forgemen were present at the hearth. In single-hand working the master finer or hammerman had only one assistant, necessitating a break in production. If, let us imagine, the master finer and his bloom-maker worked a sixteen-hour shift together then the hearth would be unoccupied for eight hours while they rested. Working double-hand therefore implied that fully fifty per cent extra could be produced in the course of the week. As a hammerman at Llangrwyney forge in Breconshire was to testify in 1790 , when working single-hand he could draw out six tonnes of bar iron per week; when working double-hand he could make between eight and ten. ${ }^{18}$ Yet there was, in fact, no fixed ratio between the output that could be achieved in double-hand working and that possible in single-hand. A double-hand forge crew might work at a stately pace whilst a single-hand crew could extend the working day to its very limits. (A Cumbrian ironmaster who witnessed single-hand production at Sutton forge in Shropshire in 1754 noted that the forgemen "have not more than three hours sleep in the twenty-four"!) ${ }^{19}$ In this way forge crews of differing composition could achieve remarkably similar results. For example: when, at the close of 1785 , each of the three fineries at Machen forge in Monmouthshire was yielding 3.18 tonnes of blooms weekly, two of the fineries were being worked double-hand, but the forge crew at the third hearth was achieving the same level of output working single-hand. ${ }^{20}$

Was the performance of the finers at Machen representative of the charcoal forge trade as a whole in the second half of the eighteenth century? Forge accounts survive in sufficient quantity to allow some provisional answers to be made. The weekly make at Machen's three fineries in late 1785 (3.18 tonnes per hearth) corresponds exactly with the average weekly output of blooms at the three finery hearths of Pentyrch forge in Glamorgan

17. For example, Glamorgan Archives (hereafter GA), D/D X 809, "Coals \& Brays deliverd to finors", records the daily delivery of charcoal to finery crews at Melingriffith in February 1780. Only on Sundays were deliveries not made.

I8. National Library of Wales (hereafter NLW), Maybery 1878, deposition of Edward Tamplin jr., 2I April 1790.

19. C. K. Hyde, "The Iron Industry of the West Midlands in 1754: Observations from the Travel Account of Charles Wood", West Midland Studies, 6 (I973), p. 40.

20. CRO, Trostre 23, James Harford to Joseph Vaughan, 23 December 1785. 
Table I. Melingriffith forge: average weekly output of blooms per finery hearth and average weekly output per finer for selected accounting years, I772-I796 (in tonnes)

\begin{tabular}{lll}
\hline & 1 & 2 \\
\hline $1772-73$ & 2.97 & 0.99 \\
$1773-74$ & 2.56 & 0.85 \\
$1777-78$ & 2.86 & 0.95 \\
$1778-79$ & 2.15 & 0.72 \\
$1779-80$ & 2.81 & 0.94 \\
$1780-81$ & 2.72 & 0.91 \\
$1782-83$ & 2.63 & 0.88 \\
$1783-84$ & 2.71 & 0.90 \\
$1785-86$ & 2.65 & 0.88 \\
$1786-87$ & 2.77 & 0.92 \\
$1790-91$ & 2.88 & 0.96 \\
$1791-92$ & 2.95 & 0.98 \\
$1792-93$ & 2.28 & 0.76 \\
$1795-96$ & 3.00 & 1.00 \\
\hline
\end{tabular}

Note. Column I is output per finery hearth per week, averaged across the forge's accounting year which ran from July to June; column 2 is the putative output per finer, assuming that each hearth was operated by a three-man crew. During the I770s Melingriffith forge operated with two fineries, and the figures in column I from I77273 to $1777-78$ therefore represent the mean of two hearths. At the end of the I770s a third finery was built, so that production figures from $1779-80$ onwards represent the mean of three hearths. (Welsh Industrial and Maritime Museum (hereafter WIMM), I991.25/I, works diary 1779.)

Sources: WIMM, 89.76I/IO, I6-20, forge accounts I772-74, I778-79, I780-8I, I783-84, I785-86; WIMM, I994.I20/642, quarterly stock accounts 1777-78; Glamorgan Archives, D/D X 809, forge accounts I779-80; WIMM, 89.76I/7-8, "reckoning" ledgers 1782-84; NLW, E. L. Chappell MSS, box 5, forge accounts I786-87; WIMM, I991.25/3-5, quarterly stock accounts I790-9I, I792-93; WIMM, 89.76I/66, yield book I79I-92; CRO, Trostre 34, forge accounts $1795-96$.

during a twenty-nine-month period from June 1790 to October 1792 (3.18 tonnes). ${ }^{21} \mathrm{~A}$ wider picture can be had from stock accounts for Melingriffith forge which are available for fourteen accounting years between 1772 and 1796. (See Table I.)

Broadly speaking, mean weekly output by a finery crew at Melingriffith remained fairly steady between the I770s and I790s, usually falling in the range 2.5 to 3 tonnes. The unusually low weekly output during the accounting year $1778-79$ is an aberrant, reflecting the temporary closure of the forge for rebuilding in the spring of 1779 . If $1778-79$, when production ceased

2I. GA, D/D Xn 3, Pentyrch cash book 1790-93. For eight of the twenty-nine months under consideration direct production figures are not given. They have to be calculated from forgemen's earnings, which probably include occasional loyalty payments ("harness money") as well as piecerate earnings. This may inflate the notional output figures, but only very slightly. 
entirely for two months, is excluded from our calculations then the overall mean weekly figure stands at 2.75 tonnes. This is congruent with the experience of other South Walian forges. It also conforms with what is known of Walloon forging in the West Midlands. A recent study of the forges at Cookley and Wolverley in Worcestershire has put the mean weekly "make" of finery crews during a I 48 week period between 1763 and 1766 at just over 2.5 tonnes. $^{22}$

This is a picture of stability. The levels of output achieved by finers across different regions seem fairly uniform. And to judge from the experience of Melingriffith forge, production norms appear to have been relatively immobile from year to year in the last decades of the charcoal era. It may be that forge plant in Britain was already subject to unusually intensive use by wider European standards. (Walloon forges in Sweden, for example, and some other areas of northern Europe, combined finery and chafery hearths one-toone, implying a more relaxed use of the forge hammer than in Britain, where a hammer crew had to serve two, or sometimes three, teams of finers at once.) $)^{23}$ Be that as it may, it seems plain enough that neither the plant nor the workforce was worked at anywhere near its physical limits. Exceptional efforts might be made by one team of finers or another, as occasion demanded, but overall levels of output remained stable. ${ }^{24}$

Coal-based refining techniques, above all that of iron puddling, brought an end to this stasis and with it the reign of forge dynasties whose ability to generalize workplace habits and standards on a pan-British basis had contributed heavily to the fixity of production norms in the charcoal forge trade. To a degree this was intended. Whilst dynasticism did have positive attributes in the eyes of ironmasters, principally by doing something to guarantee the reproduction of the workforce, ironmasters were also conscious of how dynasticism left them dependent upon a set of workers who would "admit no other man to work at the Refinery but what have been Bred up to it from Their Cradles". For many employers, the iron trade was governed by the "Ignorance and vile wickedness of forgemen": ironmasters were in thrall to workers who believed that proper accomplishment in the

22. Rydén, Production and Work, p. 49. The production of blooms was 5.I tonnes per week at both forges. Figures are not given for individual forge crews, but as two fineries were at work at both forges, output per crew is easily deduced.

23. K.-G. Hildebrand, Swedish Iron in the Seventeenth and Eighteenth Centuries. Export Industry before the Industrialization (Stockholm, 1992), pp. 59-63. The pattern of round-the-clock working in the British forge trade may also have been in advance of broader European practice. Night work in Swedish forges seems to have been an innovation of the mid-eighteenth century: see Anders Florén and Göran Rydén, "Social Organisation of the Swedish Bar Iron Production, I600I880", in Göran Rydén (ed.), The Social Organisation of the European Iron Industry I600-I9oo (Stockholm, 1997), p. I83.

24. Rydén, Production and Work, pp. 64-67, states that production at the West Midland forges of Cookley and Wolverley was usually twenty-five per cent below capacity. 


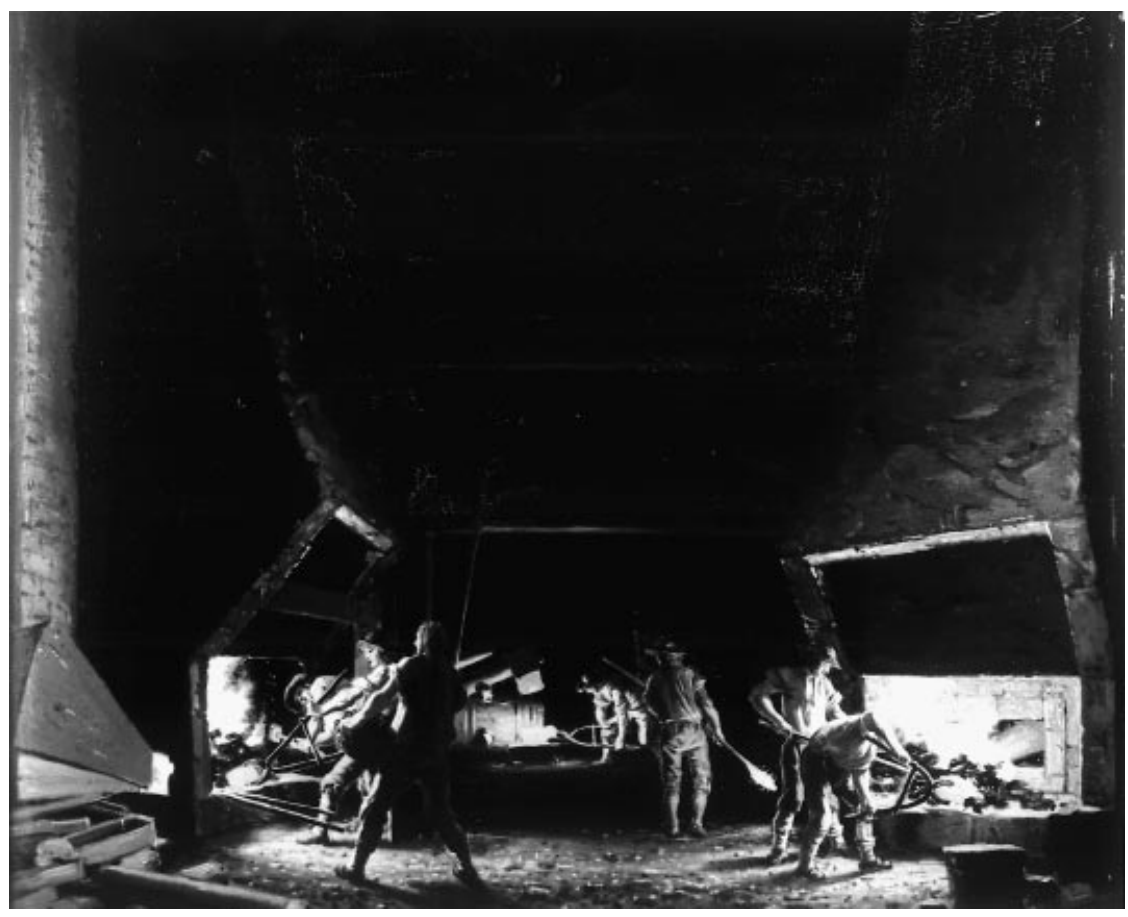

Figure 2. The interior of a Walloon forge by the Swedish painter Pehr Hillestrom, c. I790. Jernkontoret Library, Stockholm

making of bar iron "Requires forgemen that have been Breed up to those Errors". How much better it would be, one ironmaster mused, if an entirely new division of labour could be imposed "in order That These Refiners Should See Themselves of The Less Consequence, \& by which They will be proportionately Less Insolent". ${ }^{25}$ Iron puddling achieved precisely that. ${ }^{26}$

\section{II}

Henry Cort's puddling process, patented in $1783-84$, broke decisively with the form of labour organization which had prevailed under Walloon forging. The three-man finery crews of the Walloon method gave way to a simpler arrangement in which the puddler was assisted by a single underhand. The

25. NLW, Bedford papers (among the I. A. Williams papers). The quotations are from two memoranda: "Forge Hammer Practice at Kevan forge", dated 6 January 1787, and "Forge Rule Settled to Employ Carefull Labourers for forgemen", dated 26 March 1787.

26. See C. Evans, "Iron Puddling: The Quest for a New Technology in Eighteenth-Century Industry", Llafur, 4 (1994), pp. 44-57; and C. Evans, The Labyrinth of Flames: Work and Social Conflict in Early Industrial Merthyr Tydfil (Cardiff, 1993), pp. 94-I00, for a wider discussion. 
shape of the working day altered as well. Cheap and abundant energy allowed a far more intensive utilization of plant, so that in the early nineteenth century round-the-clock working, organized in two twelve-hour shifts, became the established norm, replacing the more amorphous working routines of the old charcoal regime. Most profound of all, however, was the sharp expansion in the numbers of forgemen which puddling brought about. Where two or three finery crews had once been teamed with a hammer crew, a dozen or so puddling furnaces might now be grouped together in association with a rolling mill. Forty or fifty forge workers might be deployed where once there had been only nine or ten. In such circumstances the hold which the old forge dynasties had exercised over labour recruitment and workplace practice was broken apart. ${ }^{27}$

The advent of puddling had an equally abrupt impact on output and workload within the forge. Evidence of how individual forge crews operated under the new regime is rare, but what there is is consistent. Puddling was pioneered as a commercially viable process at the Cyfarthfa works in South Wales in the late I780s. By May 1788 Richard Crawshay, the Cyfarthfa ironmaster, was able to boast that "we have got six setts of Finers to produce near thirty Tons a week", i.e. almost five tonnes per forge crew. ${ }^{28}$ This was a massive advance on the level of weekly output achieved by Walloon forging, but such levels were to become standard in the British iron trade in the early nineteenth century. Table 2 summarizes the data available to us.

These figures represent a very significant improvement on the output achieved at the old finery hearths of the eighteenth century. Their significance becomes all the greater when the composition of individual forge crews is taken into account. A crude measure of workload can be arrived at by dividing the tonnage of iron handled on a weekly basis by the number of those who worked together at a hearth. For sites which practised Walloon forging in the orthodox fashion (that is, working double-hand with finery crews comprising a master finer, a bloom maker and an apprentice) workload can be gauged by dividing the weekly output by three. This gives an average workload per finer at Melingriffith across the years 1772-I796 (but excluding the aberrant 1778-79) of 0.92 tonnes. For Pentyrch during 179092 the equivalent figure was I.06 tonnes per week. Because the puddling furnace was worked by a two-man (rather than a three-man) team, workload per forgeman was markedly higher than under the old Walloon regime, more than double the burden which a member of a finery crew had dealt

27. See S. Pollard and R. S. W. Davies, "The Iron Industry, 1750-1850", in C. H. Feinstein and S. Pollard (eds), Studies in Capital Formation in the United Kingdom, I750-1920 (Oxford, 1988), p. 89, for the expansion of the iron industry in this period.

28. Gwent Record Office (hereafter GRO), D2.I62, fo.I6, Richard Crawshay to William Reynolds, 30 May 1788. In 1791 the works manager claimed that 5.9 tonnes could be made weekly at a puddling furnace, although this possibility was discounted by Crawshay: GRO, D2.I62, fo.Io4. 
Table 2. Average weekly output of puddled bars by puddling teams and average weekly output per worker in selected early nineteenth-century forges (in tonnes)

\begin{tabular}{llll}
\hline & & 1 & 2 \\
\hline $1798-1801$ & Kirkstall, Yorkshire & 5.01 & 2.50 \\
1812 & Cradley, Worcestershire & 5.10 & 2.55 \\
1819 & Hampton Loade, Shropshire & 5.49 & 2.74 \\
$1832-33$ & Old Park, Shropshire & 4.96 & 2.49 \\
\hline
\end{tabular}

Notes. Column I is the average weekly output of individual puddling teams; column 2 is the average output per worker assuming that the puddler worked with a single underhand. A single puddling furnace was built at Kirkstall in 1797; the output figures here are for the period December I798 to January I80I. Cradley comprised two separate forges, the upper and lower; the figures given here are for the four puddling furnaces which were worked consistently at the upper forge between 28 March and 8 August I8I2. The output at Hampton Loade is that of the six teams of puddlers at work between 8 and 20 November 1819. The data from Old Park reflect the performance of the ten puddling teams that were normally at work in the year April I832 to March I833.

Sources. Kirkstall: West Yorkshire Archive Service, Leeds, K/F 5/1, Kirkstall forge wages book 1794-I802. Cradley: Dudley Archives, ZI2I, Cradley forge stock and yield accounts I805-I2. Hampton Loade: Shropshire Records and Research Unit, 5686/I, Hampton Loade stock accounts I803-36. Old Park: John Rylands Library, Manchester, BOT2/8/ 4, Old Park furnaces and forge wage accounts I832-39.

with: 2.50 tonnes per week at Kirkstall, 2.55 tonnes at Cradley, 2.74 tonnes at Hampton Loade, 2.49 tonnes at Old Park. ${ }^{29}$

The conclusion to be drawn is clear. Puddling inaugurated a new regime within the forge in which a far more intensive use was made of labour. ${ }^{30}$ Indeed, the intensity of labour in the forge seems to have become even greater after the spread of a new type of furnace lining in the I820s and I830s. The use of oxide-rich slag as a furnace lining introduced a new decarburizing agent into the puddling process, additional to the atmospheric oxygen upon which the process had originally depended. As a result, the chemical reaction in the furnace bowl was spectacularly rapid and violent (hence "pig boiling" as it was known), allowing a greater volume of pig iron

29. In making this comparison it should be noted that the work of the puddler was not exactly comparable to that of the finer. Whereas the finery crew had been responsible for shaping the loop of refined iron into a bloom at the forge hammer, under the puddling system this became the function of a specialized worker (the shingler) who serviced a number of puddling furnaces at once. However, it is doubtful whether this amended division of labour can account for more than a small part of the hastened throughput achieved by puddlers.

30. This is not to say that the money wages to be earned in the forge trade did not increase. Evidence on wage levels, as yet too fragmentary to be presented here, suggests that puddlers could earn handsome wages ("such excessive Wages as are Scandalous for us to pay": GA, D/D G I797 C-W, fo. 209, R. Crawshay to the Dowlais Co., I3 May 1797), perhaps twice what a finer might achieve, especially during the boom years of the I790s and I80os. But whereas wage rates for finers were remarkably static through the eighteenth century, piece rates for puddlers were very volatile and on a downward trend after I8IO. 


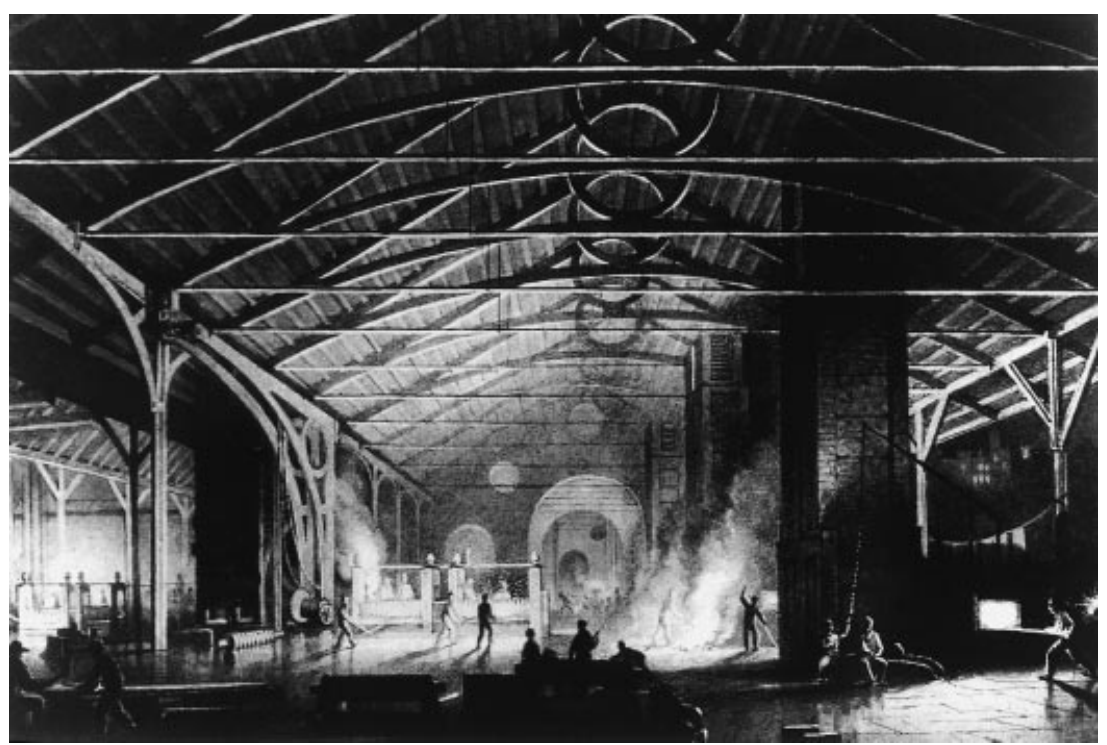

Figure 3. A rolling mill in South Wales by Penry Williams, c. I82O.

Cyfarthfa Castle Museum and Art Gallery, Merthyr Tydfil

to be decarburized within a given period, whilst a rather lower proportion of the charge was lost as acidic slag. ${ }^{3 \mathrm{I}}$ These features greatly impressed the Swedish metallurgist, A. G. Tamm, who toured Britain in the late I82os. At the Tredegar works in Monmouthshire, where pig boiling had recently been introduced, he found that a two-man puddling crew could make ten tonnes in six twelve-hour shifts. ${ }^{32}$ William Menelaus, the chief engineer of the Dowlais works at Merthyr Tydfil, was to concur: pig boiling allowed a doubling of output (and, we may presume, an upward shift in workload as well). Like Tamm, he estimated that a good puddler and his underhand could make over ten tonnes of "puddled bars" per week: that is, roughly four times the tonnage processed by a team of finers in the last days of Walloon forging. ${ }^{33}$

The claims made by Menelaus are not, in fact, fully borne out in surviving production records from Dowlais. These show the average weekly

3I. W. K. V. Gale, Iron and Steel (1969), pp.48-49.

32. A. G. Tamm and G. Ekman, "Anteckningar öfver Främmande Länders Jern-Handtering", Jernkontoret Annaler (Supplement) (I83I), pp. 79-82. My thanks to Göran Rydén for providing (and translating) this reference.

33. William Truran, The Iron Manufacture of Great Britain Theoretically and Practically Considered (London, 1855), p. 134. See R. Fremdling, "The Puddler: A Craftsman’s Skill and the Spread of a New Technology in Belgium, France and Germany", Journal of European Economic History, 20 (1991), pp. 529-567, for the heightening of workloads in the course of the nineteenth century. 
output of puddling teams in $185 \mathrm{I}-52$ to have been 7.72 tonnes. $^{34}$ Even so, this was a substantial increase on the norm under Henry Cort's original puddling method: roughly fifty per cent. The chemistry of puddling had advanced, but that advance required the application of human labour in a more concentrated form: the puddler and his helper had to load their furnace with a much heavier charge. The upward shift in workload did not escape the notice of puddlers themselves, we can be sure. A puddler at Bromford forge in the I85os complained that he had to charge his furnace with over $250 \mathrm{~kg}$ of pig iron six or seven times in the course of a twelve-hour shift, making work "much harder now-a-days than formerly, when not more than $2 \mathrm{cwts}$ or $3 \mathrm{cwts}$ [102 $\mathrm{kg}$ or $152 \mathrm{~kg}$ ] of pig iron were puddled at one heat" ${ }^{35}$ There was perhaps some pardonable exaggeration here - it seems unlikely that the charge of iron puddled in a single heat was ever as low as two hundredweight - but contemporary observers who rated puddling as the most grievously exacting occupation in the industrial world, one which led its practitioners towards premature decrepitude and death, do not seem to have been wide of the mark. The heat of the furnace bowl and the weight of iron that had to be loaded into it far exceeded what a Walloon forgeman had known in the mid-eighteenth century. To stand at the furnace door and stir about the molten metal and then to haul out incandescent balls of refined iron with nothing more than hand tongs made impossible demands upon human endurance. Puddling, one commentator announced, "taxes the muscle and strength of the operator to a greater extent than [...] any other workman engaged in the coal and iron trade" ${ }^{36}$ John Percy, the great Victorian metallurgist, was even more emphatic: "The majority [of puddlers] die between the ages of forty-five and fifty years. ${ }^{37}$

Coal technology had completely subverted the expectations surrounding

34. GA, D/D G/C 4/3, Dowlais forge production returns for the thirteen weeks ending 22 Nov. I85I and the seventeen weeks ending 20 November I852.

35. J. Percy, Metallurgy: Iron and Steel (London, 1864), p. 656. The weight of iron charged in each "heat" appears to have increased in the first half of the nineteenth century, although not from the low initial level suggested by the Bromford forgeman.

$\begin{array}{lll}\text { c. I800 } & \text { Bradley } & 178 \mathrm{~kg} \\ \text { I819 } & \text { Hampton Loade } & 178 \mathrm{~kg} \\ \text { I829 } & \text { The Level } & 191 \mathrm{~kg} \\ \text { I830 } & \text { Mayberry, Bilston } & 178 \mathrm{~kg} \\ \text { I830 } & \text { Sparrow \& Co., Bilston } & 203 \mathrm{~kg} \\ \text { c. I850 } & \text { Bromford } & 254 \mathrm{~kg}\end{array}$

Sources. Bradley: A. H. de Bonnard, "Sur les procédés employés en Angleterre pour le traitement du fer par le moyen de la houille", Annales des Arts et Manufactures, 23 (I805), p. 236. Hampton Loade: Shropshire Records and Research Unit, 5686/I. The Level: Gibbons family archive (privately held - accessed via the Historical Manuscripts Commission, London), quarterly statements of yield, I829-42. Mayberry and Sparrow \& Co.: Derbyshire Record Office, D503/5I/I, Butterley Company forge book, pp. I2, I3, 33. Bromford: Percy, Metallurgy, p. 656.

36. S. Griffiths, Guide to the Iron Trade of Great Britain (London, I873), pp. I65-166.

37. Percy, Metallurgy, p. 656. 
Table 3. Average weekly output of charcoal-refined iron by finery teams in selected early nineteenth-century forges (in tonnes)

\begin{tabular}{lll}
\hline $1827-28$ & Clydach, Monmouthshire & 11.85 \\
$1830-31$ & Pentyrch, Glamorgan & 12.18 \\
$1832-33$ & Old Park, Shropshire & 11.30 \\
\hline
\end{tabular}

Sources. Clydach: NLW, Maybery 3574, 3588, 3598, 3600, 3606a, 3618, 3628. Pentyrch: WIMM, 89.76I/55. Old Park: John Rylands Library, Manchester, BOT2/8/4.

work practice and workloads that had governed the old charcoal forge trade. Yet the new patterns of work associated with puddling were not restricted to the coal-fired sector of the iron trade. In time, they filtered back into the charcoal sector. (Here and there, charcoal forging survived, albeit at a scarcely visible level. In I854, when British bar iron output stood at over two million tonnes annually, the charcoal sector can have contributed no more than a few tens of thousands of tonnes. Nevertheless, charcoal technology continued to cater for a few niche markets which demanded bar iron of an exceptionally pure and ductile type.) The altered system of work within the vestigial charcoal sector can be observed at Pentyrch, where puddling took second place to new forms of charcoal refining, but charcoal refining that was characterized by a more intense rhythm of production and a more elaborate division of labour than had been known under the old Walloon regime. In the late eighteenth century labour had been deployed at Pentyrch in a conventional Walloon manner: three workmen at each of the forge's three fineries. ${ }^{38}$ Output per hearth also corresponded to the norm for that period, running at just over three tonnes of blooms a week. But by the I820s things had changed dramatically. Output per hearth had grown four-fold in the space of a generation. In the early I8zos (when a consistent series of data is available) forge crews at Pentyrch were making over twelve tonnes of refined metal per week. ${ }^{39}$ That this represented a new standard is suggested by output figures from other works which retained charcoal refining alongside puddling (see Table 3).

This massive increase in output was made possible by a more effective use of fuel. The open-sided finery was replaced by an enclosed, oven-like hearth in which the melting down of pig iron was considerably hastened, quickening the pace of work..$^{40}$ Moreover, fuel savings permitted an expansion in the number of charcoal hearths that could operate in any one locality. At Pentyrch the three Walloon hearths, employing nine finers, had

38. As the Pentyrch ironmaster revealed in his correspondence: "we are in great distress for Finers having but six, instead of nine - I expect three new ones from Shropshire every week". Gloucestershire Record Office, D I086/FII7, William Lewis to John Blagden Hale, 26 November 1786. 39. WIMM, 89.761/55, monthly returns of forge production at Pentyrch I826-45. Pig melting fineries at Pentyrch forge averaged I2.I8 tonnes per week in I830-3I and I2.I3 tonnes in I83I-32. 40. Percy, Metallurgy, pp. 58I-586. 
given way to five hearths of the new model by the late I820s, employing some twenty to twenty-five forgemen. Evidently, the composition of forge crews had changed: they were now four or five strong, with a more developed internal hierarchy than the three-man units of the eighteenth century. Master forgemen appear rather more in the role of supervisory workers, sometimes having charge of three or four hearths at a time. ${ }^{4 \mathrm{I}}$ In addition, the new model charcoal hearths now fed a rolling mill rather than the forge hammers of an earlier era: where the fabrication of bars had once been carried out by half a dozen haemermen it was now the responsibility of a master roller who directed the labour of twenty-five workers, distributed between seven occupational subgroups. ${ }^{42}$

In this way the intensification of labour precipitated by coal technology was generalized, not just across Britain but also into those areas of Europe that were proof against coal methods. Just as puddling brought new patterns of work to the coal basins of southern Belgium and the Ruhr, so refurbished forms of charcoal refining were exported to regions of Europe which lacked coal. Most notably, the Swedish iron industry was transformed in the midnineteenth century through the adoption of the so-called "Lancashire method", a variant of the technique used at Pentyrch. The Lancashire forge featured four or five hearths, a workforce that was three or four times the size of that to be found in traditional Swedish forges, and, from the I850s, steam-powered rolling mills on the British model. The Lancashire method brought with it a more developed division of labour, firmly defined shift patterns and a more insistent rhythm of production. ${ }^{43}$ In other words, it ushered in the "industrial" forms of organization pioneered in Britain, despite the absence of the mineral coal that had been the basis of British industrialization. ${ }^{44}$

To conclude. It is quite clear that working conditions in the forge trade were far from stable. Between the mid-eighteenth and the mid-nineteenth

4I. This conclusion has been reached by comparing the utilization of plant suggested in the accounting data for Pentyrch forge from the I830s and I840s (WIMM, 89.761/55) with the numbers of forgemen recorded in the censuses of $\mathrm{I} 84 \mathrm{I}$ and $\mathrm{I} 85 \mathrm{I}$.

42. GA, CL/MS I.I70, "B. Haddock's Memorandum Book".

43. G. Rydén, "Iron Production and the Household as a Production Unit in Nineteenth-Century Sweden", Continuity and Change, Io (1995), pp. 69-104; A. Florén, M. Isacson, G. Rydén and M. Agren, Ironmaking in Sweden and Russia: A Survey of the Social Organization of Production before I90o (Uppsala, 1992), pp. 36-38.

44. Conversely, it should be noted that in many areas of central Europe where the puddling furnace was adopted in the first half of the nineteenth century the organization of production was remained archaic. One or perhaps two puddling furnaces were combined with an old-style forge hammer to make traditional products for local markets. The high-volume production associated with the rolling mill did not prove attractive until the railway boom of the I84Os. I am drawing 
century, forgemen experienced sharp discontinuities in the workloads they were expected to shoulder. There was a rapid escalation in the performance demanded of workers. Ironmasters were able to insist upon progressively higher workloads because the power once exercised by a small and close-knit workforce over work routines and labour recruitment in the charcoal iron industry had collapsed in the face of coal-fired refining techniques.

Perhaps this was to be expected. Iron production in Britain was revolutionized at the close of the eighteenth century. But in this it was surely exceptional. Most trades retained a traditional cast. Growth across the British economy as a whole was modest and productivity gains largely restricted to the leading sectors of cotton and iron. This is the lesson of those economic historians who have, since the I970s, come to insist upon the nonrevolutionary aspect of much of British industry during the "classical" phase of the Industrial Revolution. Hand techniques predominated, organizational structures were "archaic", and the size of enterprises remained small. By and large, greater output was attained only through adding to the number of those employed in the industrial workforce, not through any advance in labour productivity. ${ }^{45}$ The experience of work, it would seem, for most workers, was not transformed. ${ }^{46}$

But, of course, the new economic history also has a quite contrary implication, one which has emerged in several recent studies of work in nonfactory centres of production: that the workplace experience of many workers was rudely disrupted. Here, the accent is upon the profound organizational changes which swept the artisanal trades during the first half of the nineteenth century. A continuing reliance on handicraft techniques did not preclude a shift in the social relations of production. On the contrary, competitive pressures led capitalist employers to compensate for the absence of technological change which might yield major gains in productivity by establishing new divisions of labour, by enforcing deunionization, by promoting a spatial redistribution of production into sweated outwork, and by restructuring the workforce in age and gender composition. The lack of spectacular technological change in "traditional" sectors of the economy did not then confer security of employment or status. ${ }^{47}$

here upon papers presented to session Q-5 of the European Social Science History Conference (Amsterdam, I998), "The Industrial Revolution and the Iron Industry in Europe", by JeanFrançois Belhoste, Chiara Mancinelli and Akos Paulinyi.

45. N. F. R. Crafts, British Economic Growth during the Industrial Revolution (Oxford, 1985).

46. P. Joyce, "Work", in F.M.L. Thompson (ed.), The Cambridge Social History of Britain, I750I950, Vol 2, People and their Environment (Cambridge, 1990), pp. I3I-I94.

47. C. Behagg, Politics and Production in the Early Nineteenth Century (London, 1990); D. R. Green, From Artisans to Paupers: Economic Change and Poverty in London, 1790-I870 (Aldershot, 1995); P. Linebaugh, The London Hanged: Crime and Civil Society in the Eighteenth Century (London, 199I); I. Prothero, Artisans and Politics in Early Nineteenth-Century London: John Gast and his Times (London, 198I); L. D. Schwarz, London in the Age of Industrialisation: Entrepreneurs, 
From this perspective must the transformation of work in iron be seen as atypical? The technological strides taken by the industry were profound, it is true. The spread of coke smelting after 1750 allowed pig iron to be produced in quite unprecedented volumes, whilst the development of steam-driven rolling mills from the I790s enabled bar iron to be processed with undreamed of speed.$^{48}$ Nevertheless, the actual refining of the metal, the central drama in the making of malleable iron, remained unmechanized throughout. ${ }^{49}$ The puddler, like his forebears in the charcoal forge trade, depended upon muscle power alone to manipulate the materials upon which he worked. Surrounded though they were by steam hammers and rolling mills, puddlers worked with a few hand-held implements at a hearth whose simple design barely changed during puddling's heyday from the I79os to the I870s..$^{\circ}$ In this respect the forge trade was somewhat paradoxical. On the one hand, it exhibited a precocious dependence upon steam power; on the other, the key chemical transformation was overseen by workmen who worked without any mechanical aid. ${ }^{5 I}$ It corresponds, in other words, to a picture of life and work in early industrial Britain that has started to become familiar in recent years: that of a handworker labouring within the context of an increasingly mechanized economy - but a worker compelled to work very much harder in this new context..$^{22}$ Just how much harder is shown graphically by the data presented here.

Labour Force and Living Conditions, I700-1850 (Cambridge, 1992). See as well, M. Berg and P. Hudson, "Rehabilitating the Industrial Revolution", Economic History Review, 2nd series, 45 (1992), pp. 3I-32.

48. C. K. Hyde, Technological Change and the British Iron Industry, I700-I870 (Princeton, 1977), pp. 53-II6.

49. J.-P. Courtheoux, "Privilèges et misères d'un métier sidérurgique au XIXe siècle: le puddleur", Revue d'histoire économique et sociale, 37 (1959), pp. I6I-I84.

50. In fact, puddling was remarkable for having no dependence whatsoever on an external motive force. Combustion in the puddling furnace was intensified by a simple chimney draught, whereas the Walloon hearth had required water-powered bellows. As Crawshay saw it, one of the advantages of puddling was that "it saves the expence and Apparatus for blowing [...]" GRO, D2.162, fo.82, Richard Crawshay to James Cockshutt, 26 November 1790.

5I. Attempts to mechanize the puddling process all failed. See Evans, "Iron Puddling", p. 54; R. B. Gordon, American Iron I607-1900 (Baltimore, 1996), pp. I50-I5I.

52. R. Samuel, "The Workshop of the World: Steam Power and Hand Technology in MidVictorian Britain”, History Workshop Journal, 3 (1977), pp. 6-72. 